\title{
KNOWLEDGE AND ETHICS
}

\section{Martin Schubert ${ }^{1}$}

\begin{abstract}
The author of the study explains human cognitive processes by referring to the scientific works of Heinz von Foerster, the Socrates of Cybernetics and co-founder of radical constructivism. The default postulate according to which "The environment as we perceive it is our invention" is supported by two experiments. The neurophysiological experiments on which the postulate is based are briefly explained and relevant ethical conclusions are subsequently drawn.
\end{abstract}

UDC Classification: 172; DOI: http://dx.doi.org/10.12955/cbup.v6.1242

Keywords: knowledge, constructivism, ethics.

\section{Introduction}

The inspiration for writing this study came from Watzlawick et al.'s book 'The invented reality' (2014) dealing with the construction of scientific, social and individual realities. The book's subtitle, 'How do we know what we believe we know?', is a seemingly simple question that incorporates three issues that have preoccupied human minds for millennia. What is known is generally considered to be the result of human exploration of the real world. Healthy human reasoning assumes that 'reality' exists. The concept suggested in the book's title, therefore, appears redundant. 'Reality' exists independent of humans, who can only 'discover' it and not invent it.

How we know is a far more vexing problem. Metaphorically speaking, human reasoning would have to exit itself to observe itself at work. The facts existing in the external world are no longer the issue. Conversely, the focus is on the mental processes with rather unclear functions. In this respect the title of the above-mentioned book makes more sense. If the way in which knowledge is obtained (how) is determined by the subject examined (what), then the portrayal of human reality depends not only on what exists externally but also on how people capture it. Socrates' predecessors also knew that people believe in the discovery of an external reality. They recognized that every reality is a construct of humans, a construct created by those who believe that they have discovered reality. However, Varela (2014) argues that people forget all that they do to contribute to the way they see reality.

Thus, what is claimed to have been discovered has been invented (conceived) although people do not realize the act of inventing it. The belief that an objective reality can be found, represents the basis of people's knowledge and thus their actions. The question of how people gain knowledge has been examined by great philosophical systems known as ontology and epistemology since time immemorial. Sadly, inventing (or the belief of discovering) has recently started to be referred to as constructivism, using a term of Anglo-American provenance. The term is somewhat confusing. In traditional philosophy, constructivism has a specific meaning and in architecture and visual art it refers to a short-lived Soviet era of movement that, apart from other avant-garde styles, "rejected subjectiveness. It denied that emotions of an individual artist were significant in art. Moholy-Nagy dictated his artwork to a professional poster artist by telephone, ..." (Little, 2012, p. 115). ${ }^{2}$

Due to these reason and others, it would be more purposeful to use the term 'study of reality' (Watzlawick, 2014, p. 10) or refer to a skeptical attitude that challenges the truism of realism (von Foerster in von Foerster \& Pörksen, 2016).

\section{Data and Methodology}

The research aims to examine the question of how knowledge originates, or more precisely, how it is constructed. The scope of the study is limited to that drawn from the work of Heinz von Foerster $(1993 ; 2012 ; 2014 ; 2016)$, which describes different processes and mechanisms on how human knowledge forms and the ethical consequences of such. von Foerster is an internationally recognized

\footnotetext{
${ }^{1}$ Matej Bel University Faculty of Education, Slovak Republic, martin.schubert@umb.sk

2 This work further develops the ideas of radical constructivism; its representatives insisted that every experience is subjective. According to its spiritual father, Ernst von Glasersfeld (1997), radical constructivism is based on the assumption that knowledge, however we define it, exists merely in people's heads; any subject capable of thinking can construct their knowledge based solely on their own experience. The way we exploit our experience creates the world in which we live.
} 
cyberneticist, biomathematician and founder of the legendary Biological Computer Laboratory (BCL), at the University of Illinois. The methods for this study were taken from the work of von Foerster. The postulate was that the environment, as an individual perceives it, is an individual's invention.

Two of the three experiments of von Foerster were examined. These were interpreted and briefly described using the related neurophysiological mechanisms to draw ethical conclusions. These two experiments were the 'blind spot' and 'changed words'.

According to von Foerster (2014, p. 40), the blind spot required a subject to perform the following:

Take this book with your right hand, close your left eye, and use your right eye to look at the star in Figure 1. Slowly shift the book along with your axis of vision back and forth until the black circle disappears (about 30-35 cm). If you still focus on the star, the circle remains invisible even when you move the book in different directions on its plane. This locally limited blindness results from the fact that no light-sensitive cells (rods and cones) are located in the area of the retina where the light-sensitive layer of the eye converge into the optic nerve. The black circle whose image is projected on this part of the retina is therefore invisible.

\begin{tabular}{|l|}
\hline Figure 1: The blind spot \\
\hline Source: von Foerster (2014) \\
\hline
\end{tabular}

However, physiological argumentation does not explain why humans fail to see the blind spot and why they are not aware of its existence. It appears as if the human field of vision is complete. There are no invisible areas. In other words, humans cannot see that they cannot see. They are blind towards their own blindness and it is a second-order case. The inability to see is applied to itself. However, a double negation (one cannot see that one cannot see) does not incite a positive answer. The fact that one sees what one cannot see does not help an individual to truly see. It means that second-order logic is in conflict with orthodox logic, dependent on which two negations result in a positive statement (von Foerster in von Foerster \& Pörksen, 2016).

According to von Foerster (2014), the changed words involved the following:

A single word is recorded on a tape and subsequently looped so that the merger cannot be identified and the recording is played on a relatively high volume. After one to two minutes of listening to the loop (50 to 150 repetitions of the recorded word), the clear and meaningful original word turns into a different clear and meaningful word. After ten to thirty repetitions this second word unexpectedly turns into a third word and so on. The short selection of 758 changed words were played to approximately 200 research subjects; they listened to the looped word 'cogitate' which subsequently turned into agitate, annotate, arbitrate, artistry, back a forth, brevity, ça d'etait, candidate, can't you see, can't you stay, Cape Cod you say, card estate, cardio tape... (p. 42)

\section{Results and Discussion}

The aforementioned experiments represent situations in which humans see or hear something that is not 'there' or, on the contrary, they do not see or hear what is 'there' until the combination of the sensation and movement enables them to 'understand' what seems to be there. This observation can be explained by the principle of undifferentiated coding. That is, nerve cell stimulation does not encode the physical nature of the stimulation caused. Only the intensity of the stimulation caused is encoded in it, i.e., 'how much' instead of 'what' (von Foerster, 2012; 2014).

In other words, signals from about a hundred million sensory cells reaching the brain do not carry any information attributed to the stimuli, except that a body part experienced some type of stimulation.

At the gate of knowledge, the putative messengers of the world are stripped of their special signs. (...) We only know that stimuli or disorder exist which is all that the nerve cell 
announces to us, however, the cause of the disorder is unclear; it is not specifically encoded. (von Foerster, 2016, p. 14)

As an example, the light-sensitive retina cell can be used similar to the rod that absorbs the electromagnetic radiation of a distant light source. Through absorption of the radiation, its electrochemical potential changes, triggering periodical electric discharge in several cells connected in the neuron bundles (ganglia), located behind the retina. The discharge frequency corresponds with the intensity of the absorbed radiation. However, it does not carry information about the fact that electromagnetic radiation was the specific cause of the rod stimulation. This applies to all sensory cells including taste buds on the tongue, tactile cells, or other receptors through which smells, temperature, sound, for example, are perceived. They are 'blind' towards the stimuli quality and respond solely to stimuli quantity. 'Out there', no light or color physically exists, but rather there are electromagnetic waves; there is no sound or music, but rather there is a periodical change in the air pressure (von Foerster, 2014). Further, there is no cold or warmth, but rather there are molecules with bigger or smaller kinetic energy and last, but not least, 'out there', there is no pain (von Foerster, 2014).

Since the physical nature of the stimulus, its quality, is not communicated through the nervous activity, a key question arises about how an individual's brain produces the diverse world they experience every moment, awake or asleep. This question can be formulated as the 'issue of knowledge' or the study of cognitive processes. The subject of the study is 'knowledge', which von Foerster (2014) described as "knowledge $\rightarrow$ computation of a reality" (p. 44).

It appears that the unknown term 'knowledge' has been replaced with three different words. Paradoxically, the most definite of these is the indefinite article 'a'. However, this article evokes the notion that there are other 'realities' apart from the one of an individual's environment. 'Computation' evokes the notion that social order, numbers, formulae, symmetry, natural laws, objects, and taxonomy are not actually 'there' but merely computed.

Computation in von Foerster's work does not refer to numerical phenomena. The Latin word, computare, means to combine items in a context. 'Com' can be translated as 'together' and 'putare' means to assume or evaluate. Computation in general means that multiple stimuli and sensations entering the body are contextually combined by the nervous system. These transitions in the nervous system can be understood as a computation that refers to active processes and moments of creation (von Foerster, 2014; von Foerster \& Pörksen, 2016).

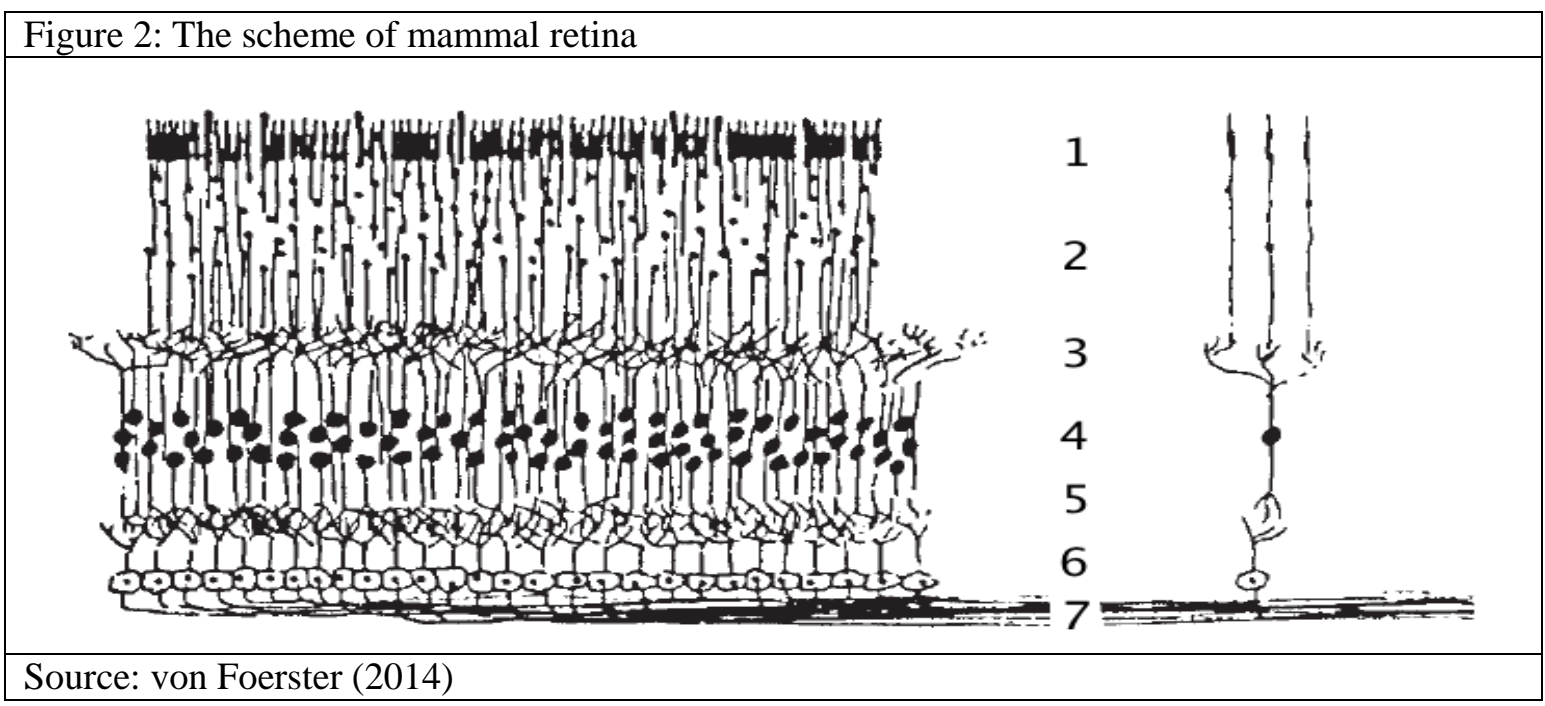

A typical example of a computation unit is the retina in the nervous tissue of vertebrates. Figure 2 shows a schematic of a mammal retina with the underlying neural network. The first layer comprises rods and cones with bodies and cores located beneath them in a second layer. In the third layer, the axons of light-sensitive cells are connected to the dendrites of bipolar cells through synapses (fourth layer). In the fourth layer, the bipolar cells are again connected by synapses to the dendrites of ganglia, which create the sixth layer. Electric signals from the ganglion cells are transferred into the 
deeper brain regions through axons bundled into the optical nerve (seventh layer). The computation processes take place in the third and fifth layers, where synapses are located. This is where color and other impressions, such as form, are computed (von Foerster, 2014).

The expressions ' $a$ ' reality and 'the' reality represent two different ways of thinking, but each refers to explanatory principles of correlation and confirmation. For example, the correlation between tactile and visual perception creates an experience that can be described as 'a table is standing here'. In the context of the other principle, tactile perception confirms the visual perception of that same experience.

von Foerster (2014) rejects the confirmation principle, due to epistemological reasons, as it transfers the issue of knowledge into a 'blind spot' of knowledge where the absence is also not visible. It can be stated that cognitive processes compute descriptions of clocks or galaxies instead of these as objects. von Foerster, therefore, adjusts the original formula "knowledge $\rightarrow$ computation of a reality" to the following: "knowledge $\rightarrow$ computation of the phenomena of a reality" (p. 46).

A depiction, such as an image projected on the retina, that is computed on the neural level is further processed at a higher level. The observer's motor activities can also contribute to the 'final description' of 'a table is standing here'. Thus, von Foerster (2014) concluded that the formula needed to be readjusted to the following: knowledge $\rightarrow$ computation of descriptions of descriptions of descriptions... (p. 46).

This unlimited repetition of the description removes one unknown 'reality'. It emerges only implicitly as a process of recursive description. Computing descriptions are also computing. This implies that: knowledge $\rightarrow$ computation of computation of computation... (p. 46).

Cognitive processes can, therefore, be understood as infinite recursive computations that are at the base of life itself. ${ }^{3}$ According to von Foerster (2014), cognitive processes can be observed on two levels:

1. In the operations performed, and

2. In the arrangement of these operations that represent the nervous system structure.

In computer language, level 1 is referred to as an 'operation' and level 2 as 'program'. Because programs of 'live computers' can auto-compute, meta and meta-meta program concepts arise. Such systems are characterized by a recursive arrangement. Computing operations follow the non-trivial rule of 'cognitive homeostasis', where the nervous system is arranged or arranges itself in a way that allows it to compute a stable reality (von Foerster, 2014). ${ }^{4}$ This rule further implies the postulates of independence and self-reference.

The independence postulate is as follows: "The living organism is an independent and autonomous being with a definite arrangement" (von Foerster, 2012, p. 42).

This postulate is the result of the new biology (and neurophysiology) in which the arrangement of the ever-renewing integrity of all living organisms represents the starting point for deriving specific functions. If the postulate is extended to its logical limits, it becomes a solipsism of 'I am the only existence!' This view has been raised in different generally known forms, e. g., by Descartes with Cogito ergo sum (I think, therefore I am!) and Berkeley with Esse est percipi (To be is to be

\footnotetext{
${ }^{3}$ The nervous system is a part of humans as biological beings and autonomous units. The nervous system itself also refers to itself in various ways. It is because all nervous activity (movement, internal secretion) directly stimulates the sensory surface. Just like neurons affecting each other through their proximity in the synapses, groups of muscles affect the bodily sensations by re-affecting the sensorimotor synapses. Motor stimuli cause sensory consequences and sensory stimuli have motor consequences. The principle of reafference applies universally (Varela, 2014).

${ }^{4}$ In mathematics, the term can be understood as invariant computation: computation of stable values in a constant transformation process. Heinz von Foerster (2016) explains the idea using a cube. Take a cube and examine its edges. By swaying our head and turning the cube we create new correlations between our motor and sensory activities and the nervous system starts computing invariants. What we refer to as "the object", e. g. the cube, is basically a competence of our nervous system that enables it to compute invariants. The object is the symbol of our ability to compute invariants.
} 
perceived). However, there are also philosophers who consider solipsism as incoherent and bizarre or a philosophical scandal (Kant). The most interesting attribute of solipsism is that it cannot describe itself.

However, this inability can be overcome by the self-reference postulate of "The observing organism itself is a part, co-owner and participant of the world it observes" (von Foerster, 2012, p. 43).

This postulate is the result of the new logic (and mathematics) that involves the study of a phenomenon that can be applied to itself and which needs itself to originate. Computing of a brain theory, T (B), is an example. According to von Foerster (1993), the theory must be created by the brain. Therefore, B (T) is arranged in a way to allow it to write itself, T (B (T)). Therefore, the brain theory is significantly different from certain theories in physics that (not entirely successfully) aim to describe a 'world without subjects' where the observer also has no place. Based on this premise, von Foerster formulated Theorem No. 3: "Laws of nature are written by humans. Laws of biology must write themselves." (von Foerster, 1993, p. 170).

The brain theory resembles the workings of language. Language is an exceptional and complex phenomenon. The complexity of such is difficult to explain. In fact, it can only be practiced. ${ }^{5}$ Just as humans need a brain to think about the brain theory, they need the complexity of language to describe the complexity of language. The power of both these notions derives from the fact that each phenomenon needs itself to originate. They are of a second order nature (von Foerster, 1993).

Language resists explanation. The word for language is 'language'; the word for the word is 'word'. If individuals did not know the meaning of 'word', they would consult a dictionary. The same applies to 'speaking' and 'to speak' which mean to 'use words to express oneself' (Kačala et al., 2003, pp. 196 $\&$ 678). Hence, it is a circularity with A implying A.

Figure 3: A man with a hat and a briefcase

\footnotetext{
${ }^{5}$ For example, Noam Chomsky explained language through the existence of a "language organ" stored in our brains. He reduced the whole language to a formal syntax (grammar) regardless of the social reality (Čermák, 2011). If the language can be explained ontologically by referring to some kind of a wondrous organ, nothing prevents us from interpreting our mathematical skills through the existence of a "mathematical organ" with specialized organelles for addition, subtraction or multiplication (von Foerster, 1993). All our problems could be solved like this. We just need to make up a thing that can supposedly cause or remove them. In fact, these are just excuses so that we do not have to admit: "I cannot answer this question."
} 
Extending this postulate to its logical limits presents an 'omnipsism' (Lat. 'omnis' all; 'ipse' itself), i. e., a notion that the subject who imagines the word creates a reality that includes everyone: "We exist through all of ourselves!" This notion also has many predecessors and generally known forms, e. g., Frankl: "We see ourselves through the eyes of other people" and Kant: "Act only in accordance with that maxim through which you can at the same time will that it become a universal law."

Although people are free to accept solipsism, according to the principle of relativity, the solipsist hypothesis is rejected, since it cannot be generalized. For example, inhabitants of both Earth and Venus would agree that they live in the center of the universe. However, these expectations would never be sustained should they ever meet. In the case of a conflict arising between them, it could be settled with each accepting heliocentrism. Figure 3 depicts a person with a hat, a convinced solipsist, who believes they represent the only reality and everything else exists because of their imagination. However, they cannot deny that this imaginary world is inhabited by apparitions resembling themselves. Therefore, they must admit that these beings can also insist that they are the only reality and everything else is the product of their imagination. Their worlds would also be inhabited by apparitions and one would be the person with the hat (compare von Foerster, 2012; 2014; 2016).

The central reference quantity in case of this person is their imaginary world. When it is externalized, a medium is created where the relationship between 'You' and 'Me' takes place. 'Me' exists through another person (You) and 'You' exists through 'Me', reflecting each other's behavior. The consciousness of 'Me' about 'You' is, therefore, the self-consciousness of 'Me' (Wissen and GeWissen; von Foerster, 2012).

On the one hand, the principle of relativity is not a logical requisite. People are free to decide whether to accept it or not. Where they reject it, their language becomes a monologue; they talk to themselves. The language is denotative and relates to external objects by pointing at them. What one says is descriptive. They describe what is happening, for example, 'a table is standing here' and 'an armchair there'. This concept is the basic principle of journalism: 'tell it as it is'. The language is also grammatical in terms of its expression, e.g., understanding the grammatical (syntactic) relationships between nouns. In Cogito, ergo sum! (I think, therefore I am!) a reference to another person is missing entirely. This is how the consciousness of oneself emerges: 'I am aware of myself, therefore I am'.

On the other hand, in accepting the principle of relativity, one's language becomes dialogic and connotative. People address the notions of objects in the minds of others rather than as objects themselves. The 'music' of language causes resonance in another 'musical instrument'. In this case, the language is not descriptive; it is constructive. People encourage each other to create a world about which they would like to talk. Where one succeeds, others experience what they created on their own and which exists in their own story. This contradicts the principle of journalism: 'I will tell you as it is'. One cannot describe the quality of it because 'it' has ceased to exist, apart from enduring as a memory of those who talk about it. In this case, the nature of the language is semantic, not grammatical. Descartes would say, Cogito, ergo sumus (I think, therefore We are). Consciousness originates when a person cohabitates with another person (von Foerster \& von Glasersfeld, 2010) and the ethic manifests invisibly through dialogue. Thus, it is imperative to always act in a way that increases the number of options (von Foerster, 1993; 2014; von Foerster \& Pörksen, 2016).

The ethical requirement means that people are expected to act in a way that increases the freedom of others and society as a whole. The greater the freedom, the larger the number of opportunities to claim responsibility for one's actions. Freedom and responsibility are interconnected. Only a free person, one free to act differently if they wish, can act responsibly. This means that a person who deprives or restricts another of freedom also denies the opportunity for another to act responsibly and this in itself is irresponsible (von Foerster in von Foerster \& Pörksen, 2016).

In regard to knowing the knowledge, Maturana \& Varela (2016) considered the following:

It forces us to admit that surety is not an evidence of the truth. It forces us to realize that the world that each of us sees is not the only world, it is a world that we form together with the others. It forces us to realize that the world will only be different if we live differently. It binds us because when we know that we know, then we cannot deny the fact that we know in front of ourselves or the others.... the fact that we know incorporates an ethic from which we cannot escape, an ethic whose reference point is the awareness of the biological and social 
structure of human beings, an ethic that stems from human thinking and which puts the human reflection into the very center as the main social phenomenon. If we know that our world is invariably the world that we form together with the others, every time we are in a conflict with another human being with whom we would like to coexist, we cannot insist and claim things of which we are sure (absolutely true) because we would negate the other person. If we wish to coexist with the other person we must understand that the other person's surety, however undesirable it seems to us, is just as legitimate and valid as our own one. (pp. 218219)

\section{Conclusion}

Solving the research problem, 'knowing the knowledge and its impact on the ethical observation', has led to the conclusion that 'knowing the knowledge' is binding. Notably, the physical world of the living, the self-referent logic, and the entire natural history indicate that the ethics of one's reflection on the legitimacy of others' presence is the beginning and the end of all knowledge.

\section{Acknowledgment}

The study is a part of the VEGA Ministry of Education, Science, and Research of Slovak Republic No. 1/0581/16 "Andragogic Ethic in the Theory of Adult Education" research grant.

\section{References}

Čermák, F. (2011). Jazyk a jazykověda : Přehled a slovniky. Praha: Karolinum.

Foerster, H. von. (1993). KybernEthik. Berlin: Merve Verlag.

Foerster, H. von. \& Glasersfeld, E. von. (2010). Wie wir uns erfinden. Eine Autobiographie des radikalen Konstruktivismus. Heidelberg: Carl-Auer Verlag.

Foerster, H. von. (2012). Entdecken oder Erfinden: Wie läßt sich Verstehen verstehen? In Einführung in den Konstruktivismus. München; Zürich: Piper Verlag, pp. 41-88.

Foerster, H. von. (2014). Das Konstruieren einer Wirlichkeit. In Watzlawick, P. (ed.). Erfundene Wirklichkeit: Wie wissen wir, was wir zu wissen glauben? Beiträge zum Konstruktivismus. München: Piper Verlag, pp. 39 - 60 .

Foerster, H. von. \& Pörksen, B. (2016). Pravda je vynález lhář́: Rozhovory skeptiků. Praha: Pragma.

Glasersfeld, E. von. (1997). Radikaler Konstruktivismus: Ideen, Ergebnisse, Probleme. Frankfurt a. M.: Suhrkamp

Taschenbuch Verlag.

Glasersfeld, E. von. (2014). Einführung in den radikalen Konstruktivismus. In Watzlawick, P. (ed.) Erfundene Wirklichkeit: Wie wissen wir, was wir zu wissen glauben? Beiträge zum Konstruktivismus. München: Piper Verlag, pp. 16 - 38.

Kačala, J. a kol. (2003). Krátky slovník slovenského jazyka. Bratislava: Veda.

Little, S.(2012). ...izmy : ako im rozumiet'. Bratislava: SLOVART.

Maturana, H. R. \& Varela, F. J. (2016). Strom poznání: Biologické základy lidského rozumu. Praha: Portál.

Varela, F. J. (2014). Der kreative Zirkel Skizzen zur Naturgeschichte der Rückbezüglichkeit. In Watzlawick, P. (ed.) Erfundene Wirklichkeit: Wie wissen wir, was wir zu wissen glauben? Beiträge zum Konstruktivismus. München: Piper Verlag, pp. $294-309$.

Watzlawick P. (2014). Vorwort. In Watzlawick, P. (ed.) Erfundene Wirklichkeit : Wie wissen wir, was wir zu wissen glauben? Beiträge zum Konstruktivismus. München: Piper Verlag, pp. 9 - 11. 